\title{
PoCHL P expression pattern in Posidonia oceanica is related to critical light conditions
}

\author{
A. Bruno ${ }^{1, *}$, L. Bruno ${ }^{1, *}$, A. Chiappetta ${ }^{1}$, D. Giannino ${ }^{2}$, M. B. Bitonti ${ }^{1, * *}$ \\ ${ }^{1}$ Department of Ecology, University of Calabria, 87036 Arcavacata di Rende (CS), Italy \\ ${ }^{2}$ CNR - Institute of Biology and Agricultural Biotechnology, 00015 Monterotondo Scalo, Rome, Italy
}

\begin{abstract}
In past decades, meadows of Posidonia oceanica (L) Delile have declined extensively in the Mediterranean basin mainly due to disturbances associated with reduced light availability. To investigate the molecular mechanisms of photoacclimation in this seagrass, we selected the CHL $P$ gene as a marker of plant response to light availability because it is involved in the chlorophylltocopherols biosynthetic pathways. After characterizing the PoCHL P gene, its expression pattern was analyzed in leaves of plants growing in 2 distinct meadows that were previously categorized as disturbed and preserved. Plants were sampled during different seasons and light availability was monitored in the selected meadows over a $1 \mathrm{yr}$ period. PoCHL $P$ expression was also analyzed in leaves of plants that were exposed to controlled light conditions in aquaria. We found that PoCHL $P$ was expressed differentially with respect to leaf developmental stage and that its expression pattern changed rapidly under light conditions far below the compensation value established for $P$. oceanica. Hence, the recognition of this gene as a reasonable marker of critical light conditions provides an important step towards the functional characterization of stress-related genes in seagrasses.
\end{abstract}

KEY WORDS: PoCHL P expression · Posidonia oceanica $\cdot$ Light availability

\section{INTRODUCTION}

Prolonged human activities in coastal areas of the Mediterranean basin have significantly influenced the quality of the marine environment and its hydrodynamic regime (Short \& Wyllie-Echeverria 1996, Cancemi et al. 2003). One of the most relevant indicators of habitat degradation in this region is water turbidity, which threatens the survival of submersed plant species by reducing light availability (Marbà et al. 1996, Short \& Wyllie-Echeverria 1996, Acunto et al. 2006). Unquestionably, light is a critical ecophysiological factor for plants. It not only influences resource synthesis through photosynthesis, but also modulates hormonal levels (Davies 1995) and signalling cascades (Sweere et al. 2001, Hutchison \& Kieber 2002, Monte et al. 2007), which in turn regulate plant growth and development. Thus, the ability to elicit specific responses in relation to light quantity and quality represents a fundamental adaptation of plants to their native environment. Understandably, plants grown under prolonged light deprivation often exhibit decreased metabolic activity, predictably leading to premature senescence (Weaver \& Amasino 2001, Lin \& Wu 2004). Notably, light attenuation is a key factor affecting the growth and depth distribution of different seagrasses (Dennison 1987, Duarte 1991).

Posidonia oceanica (L) Delile is the most widespread and ecologically important seagrass of coastal Mediterranean ecosystems (Jeudy de Grissac \& Boudouresque 1985, Pergent-Martini et al. 1994, Alcoverro et al. 1997). Due to its sensitivity to environmental perturbations, P. oceanica is widely recognized as a bioindicator of sea quality in this region (Pergent et al. 1995, Ferrat et al. 2003, Ruiz \& Romero 2003, Tranchina et al. 2005, Lafabrie et al. 2007, Montefalcone 2009). The $P$. oceanica meadows have 
declined significantly throughout the Mediterranean basin over the past 2 decades (Marbà et al. 1996, Short \& Wyllie-Echeverria 1996). In this context, we sought to obtain specific insights to help us understand how this particular seagrass responds to altered light availability. In the present work, we identified the GERANYLGERANYL REDUCTASE (CHL P) gene in $P$. oceanica, which encodes a multifunctional chloroplastic enzyme involved in both chlorophyll (chl) and tocopherol (TP) biosynthesis (Keller et al. 1998). This gene functions in vegetative growth and stressdefense mechanisms, mainly by protecting plastid membranes against oxidative stress through TP action (Kamal-Eldin \& Appelqvist 1996). Accordingly, the $C H L P$ gene is a reasonable candidate marker for studying light-stress responses of $P$. oceanica at the molecular level.

To date, $C H L P$ has been studied in red algae (Bollivar et al. 1994), cyanobacteria (Addlesee et al. 1996) and in some terrestrial dicots, where its role in stress responses has been emphasized (Keller et al. 1998, Giannino et al. 2004, Bruno et al. 2009a). However, in monocots, information on CHL $P$ orthologs exists mainly as a result of sequencing projects (Zea mays, GenBank: NM_001155910, and Oryza sativa, GenBank: Q6Z2T6) or direct database submission (Triticum aestivum, GenBank: DQ139268) (Alexandrov et al. 2009, International Rice Genome Sequencing Project 2005). To date, the function of CHL $P$ has not been examined in any monocot, including all of the seagrasses, although a limited number of genes was generally investigated in the latter (Giordani et al. 2000, Cozza et al. 2006, Cozza \& Pangaro 2009). In addition, a partial expressed sequence tag (EST) database of $P$. oceanica reporting 1219 tentative unigenes has recently been released (Wissler et al. 2009).

To investigate the putative role of the PoCHL $P$

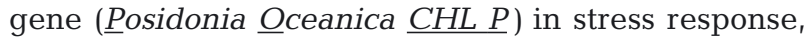
we studied its expression pattern in $P$. oceanica growing in 2 distinct meadows. These meadows were previously classified as preserved and disturbed based on crucial ecological descriptors (Rende et al. 2005, Acunto et al. 2006), hormonal parameters (Cozza et al. 2004, Bruno et al. 2009b) and proteomic data (Mazzuca et al. 2009). Because the disturbed site was characterized by higher water turbidity (Rende et al. 2005, Acunto et al. 2006), the present study monitored light conditions in the 2 meadows over a 1 yr period. Expression of the PoCHL $P$ gene was analyzed in leaves of plants that were sampled during different seasons as well as in those grown in aquaria under selected light conditions. In this way, we tested the extent to which PoCHL $P$ was expressed differentially in relation to leaf development and light availability.

\section{MATERIALS AND METHODS}

Field sites. Plant material was collected in 2 Posidonia oceanica meadows located $3 \mathrm{~km}$ apart along the western coast of Calabria (Italy): a disturbed meadow (DM) $\left(39^{\circ} 48^{\prime} 45.71^{\prime \prime} \mathrm{N}, 1^{\circ} 47^{\prime} 53.74^{\prime \prime} \mathrm{E}\right)$, and a preserved one (PM) $\left(39^{\circ} 54^{\prime} 28.83^{\prime \prime} \mathrm{N}, 1^{\circ} 46^{\prime} 28.38^{\prime \prime} \mathrm{E}\right)$ (Acunto et al. 2006). From June 2005 to May 2006, light (lx) and temperature $\left({ }^{\circ} \mathrm{C}\right)$ parameters were recorded every 30 min using a data logger (Hobo Pendant, Onset Computer Corporation) with a measurement range of 0 to $320 \mathrm{klx}$. The sensors were anchored in each meadow at $10 \mathrm{~m}$ depth. For light analysis, at each season (summer, autumn, winter and spring), specific time intervals per day $(\mathrm{T})$ were considered: T-I (from 5:00/7:00-11:00 h), T-II (11:00-15:00 h) coincident with sampling time, and T-III (15:00-18:00/20:00 h). For the comparison between preserved and disturbed sites, statistical analysis was performed for each season plus T-time intervals using 1-way ANOVA. A post-hoc Neuman-Keul's test was used when the p-value was significant $(<0.05)$.

Sampling of plant material. PM and DM plants were sampled at a depth of $10 \mathrm{~m}$ during different seasons (i.e. summer: June 2005; autumn: November 2005; spring: April 2006), which reflected different growth rates and metabolic states of P. oceanica (Ott 1979, Pirc 1985, Pirc 1986, Zupo et al. 1997). The winter season was excluded because it is a metabolic resting period for this plant species. Excised shoots, leaves and rhizomes were frozen in liquid nitrogen or fixed for in situ hybridization. Leaves were categorized as young (YL), intermediate (IL) or adult (AL) according to Giraud (1977), but only the first $2 \mathrm{~cm}$ of apical portions were used. Before fixation or freezing, epiphytes were gently removed from leaves using a sterile razor blade.

Aquarium experiments. Subsets of PM and DM plants ( $\mathrm{n}=12$ for each sample) collected in April 2006 were transferred into 2 aquaria containing $100 \mathrm{l}$ of seawater $\left(\mathrm{pH} 7.8,15.5 \pm 0.5^{\circ} \mathrm{C}[\mathrm{SE}]\right)$ and provided with a water flow-through system and aeration throughout the course of the experiments. Plants were acclimated for $3 \mathrm{~d}$ under light conditions recorded at the T-II interval of the week before sampling. Thereafter, PM $(n=6)$ and DM $(n=6)$ plants were positioned side by side in each aquarium and exposed to either (mean $\pm \mathrm{SE}$ ) $3.37 \pm 0.5$ (L1) or $1.7 \pm 0.4 \mu \mathrm{mol} \mathrm{m} \mathrm{m}^{-2} \mathrm{~s}^{-1}$ (L2), corresponding to the T-II mean values recorded in June in the PM and DM meadows, respectively. An incandescent lamp (15 W) was positioned at an adequate distance to achieve the desired conditions and was constantly monitored using the Hobo Pendant data logger. The selected light conditions were applied from 11:00 to $15: 00 \mathrm{~h}$, coincident with the T-II interval. For the remaining periods, the aquaria were exposed to ambi- 
ent room light conditions, which ranged from 1 to $0 \mu \mathrm{mol}$ $\mathrm{m}^{-2} \mathrm{~s}^{-1}$ (Fig. S1 in Supplement 1 at www.int-res.com/ articles/suppl/m415p061_supp.pdf). After treatment, plant material (shoot apices, leaves, rhizomes and roots) was excised and frozen immediately.

Light data conversion. Photometric units that were provided by the Hobo sensors (lx) were converted into radiometric units $\left(\mu \mathrm{mol} \mathrm{m} \mathrm{m}^{-2} \mathrm{~s}^{-1}\right.$ ) using the conversion factors (18 and 20 for daylight and incandescent light sources, respectively) previously reported by McCree (1981). Importantly, McCree's conversion is based on measurements performed in air. Thus, measurements taken under water at $10 \mathrm{~m}$ depth are approximate and relative rather than absolute, whereas values estimated for the aquaria are fairly close to the absolute.

Total RNA extraction and reverse transcription. Total RNA was extracted from samples following the procedure of Doyle \& Doyle (1990) with some modifications. All solutions were prepared with RNase-free distilled water. Tissues (300 mg) were ground in liquid nitrogen while adding 0.1 g PVP-40 (polyvinylpyrrolidone, Sigma) directly to the mortar. One $\mathrm{ml}$ of freshly prepared extraction buffer, i.e. $200 \mathrm{mM}$ Tris/ $\mathrm{HCl} \mathrm{pH} \mathrm{7.5,} \mathrm{1.4} \mathrm{M}$ $\mathrm{NaCl}, 20$ mM EDTA, $3 \%$ hexadecyltrimethylammonium bromide $(\mathrm{CTAB}, \mathrm{w} / \mathrm{v})$ and thereafter $\beta$-mercaptoethanol (final concentration 1.3\%), were added to the samples. After $30 \mathrm{~min}$ incubation at $60^{\circ} \mathrm{C}, 1$ volume of chloroform/isoamyl alcohol (49:1) was added. After centrifugation at $6500 \mathrm{rpm}$ for $15 \mathrm{~min}$, the supernatant was recovered and precipitated overnight with isopropanol at $-20^{\circ} \mathrm{C}$. After centrifugation at $13000 \mathrm{rpm}$ for $15 \mathrm{~min}$ and washing with $0.2 \mathrm{M}$ sodium acetate/70\% ethanol for $1 \mathrm{~h}$ at $4^{\circ} \mathrm{C}$, RNA was resuspended in RNase-free water and treated with $30 \mathrm{U}$ of DNase I (Roche) for $15 \mathrm{~min}$ at $37^{\circ} \mathrm{C}$. The quality and quantity of RNA was verified using a spectrophotometer (NanoDrop ND-1000) and the integrity was checked electrophoretically on $0.8 \%$ agarose gels. Total RNA (1 $\mu \mathrm{g})$ from each sample was reverse transcribed with the SuperScript III reverse transcriptase and oligo dT(22) according to the manufacturer's instructions (Invitrogen).

Isolation and sequence analysis of cDNA and genomic clones. Leaf cDNA was amplified by PCR using the primers FW1 (5'-GTG CTG GCG GTN GAY GAY AG-3') and BW1 (5'-GCG GAC GGG CTT NAG NAG$\left.3^{\prime}\right)$, which were selected within the region of highest conservation between tobacco and Arabidopsis. The resulting fragment was $911 \mathrm{bp}$ long and homologous to the CHL $P$ of the above mentioned plants. The 3 ' region was identified by the 3 ' RACE according to the manufacturer's instructions (Invitrogen) using a provided primer and the primer FW2 (5'-CAA GGC CTA GAA GGT TGC TG-3'). The 5' region was isolated using primer BW5R (5'-ACT CTC CGG TCG ATG ATG TC-3') and kit anchor primers (Invitrogen). Introns were identi- fied by amplifying leaf genomic DNA (gDNA) with the following primers: FW1/BW1 and FW3 (5'-GGC CAG TAA GCC TTG TCA AC-3')/BW3 (5'-GAG ACA TCG TCC TTG GGA GA-3') (see Fig. 2A). Exon-intron boundaries were annotated by aligning the obtained genomic sequences with the full-length cDNA and comparing the results using 2 web programs (Plant Gene Data Bank server, www.plantgdb.org/cgi-bin/GeneSeqer/ index.cgi, and ClustalW, www.ebi.ac.uk/clustalw/).

PCR components were $500 \mathrm{ng}$ of gDNA or $200 \mathrm{ng}$ of cDNA, $1 \mathrm{mM}$ of each primer, $0.5 \mathrm{mM}$ of dNTP, $2.5 \mathrm{U}$ Taq DNA polymerase (GoTaq, Promega), 1/5 of 5X Taq buffer, and $7.5 \mathrm{mM}$ of $\mathrm{MgCl}_{2}$, in a final volume of $50 \mu \mathrm{l}$.

Thermocycling conditions used for gDNA PCR, cDNA and RACE-PCR experiments had a common initial cycle of $94^{\circ} \mathrm{C}$ for $3 \mathrm{~min}$. The subsequent 35 amplification cycles were performed at $94^{\circ} \mathrm{C}$ for $40 \mathrm{~s}, 60^{\circ} \mathrm{C}$ for $60 \mathrm{~s}$ and $72^{\circ} \mathrm{C}$ for $90 \mathrm{~s}$ for gDNA, and at $94^{\circ} \mathrm{C}$ for $40 \mathrm{~s}$, $55^{\circ} \mathrm{C}$ for $30 \mathrm{~s}$, and $72^{\circ} \mathrm{C}$ for $30 \mathrm{~s}$ for cDNA. A final extension step at $72^{\circ} \mathrm{C}$ for 5 min was a common feature of both amplification thermal profiles. Multiple clones of all PCR fragments were cloned into the pGEM-T-Easy vector system (Promega) and sequenced by the Genelab ENEA service (Rome, Italy). Sequencing of overlapping fragments did not identify any differences or the presence of single nucleotide polymorphisms (SNPs).

Southern blot. gDNA was extracted from leaves following the Doyle \& Doyle (1990) protocol. Southern blots and hybridizations were performed as described in Bruno et al. (2009a). Briefly, $10 \mu \mathrm{g}$ of gDNA was restricted overnight at $37^{\circ} \mathrm{C}$ with $S p h I$ and SpeI endonucleases (Promega), which do not cut in the probe (see Fig. 2A), in a $20 \mu$ final volume. Digested DNA was precipitated, resuspended and electrophoresed for $20 \mathrm{~h}$ at $45 \mathrm{~V}$ on $0.8 \%$ agarose gel and vacuum blotted onto Hybond-N+ membrane (Amersham Pharmacia Biotech). Digoxigenin (DIG)labeled probe 2 (see Fig. 2A) was obtained after PCR amplification using $10 \mathrm{ng}$ of gDNA, DIG-dNTPs (Roche) and primers FWS (5'-TGC GCT TGT TAC CAG AAC AC-3') and BWS (5'-GCT GCG AAG TAG ATG CCT TC-3'), according to the manufacturer's instructions (see Fig. 2B). Prehybridization (3 $\mathrm{h}$ at $52^{\circ} \mathrm{C}$ ) and hybridization (overnight at $52^{\circ} \mathrm{C}$ ) were carried out in 20X SSC $(3 \mathrm{M} \mathrm{NaCl}, 300 \mathrm{mM}$ sodium citrate), $0.01 \%$ sarkosyl $(10 \%)$, and $0.1 \%$ blocking reagent (2.5\% prepared in maleic acid buffer, $\mathrm{pH} 7.5)$ in a hybridizer (HB-2D, Techne). Detection was performed with anti-DIG-AP (Roche), nitro blue tetrazolium chloride (NBT) and 5-bromo-4-chloro-3-indolyl phosphate (BCIP) following the manufacturer's instructions (Roche). Hybridization bands were visualized by keeping the membrane in the dark for $2 \mathrm{~h}$ (blocked with Tris-ethylenediaminetetraacetic acid, TE) and then computer scanned (UMAX SPEED II). 
In situ hybridization. Excised tissues were fixed, dehydrated, embedded in paraffin and cut into $8 \mu \mathrm{m}$ sections. Hybridizations were performed according to the procedure of Cañas et al. (1994), using the probe 1 spanning the 1162-1483 stretch which was cloned after PCR amplification with FW4 (5'-ACA AGG TGC TCG ATG TGT TG-3') and BW4 (5'-CCC AGA TTC CCC TCT ACA GC-3') primers. DIG-labeled RNA sense and anti-sense probes were obtained as described in Bruno et al. (2009a). Immunological detection was as reported by Chiappetta et al. (2009). Transcript accumulation was visualized as a violet/brown staining.

Semi-quantitative RT-PCR analysis. Primers used for PoCHL P, 223 bp were SeQFW (5'-ATC TCC GCC AAG TCC TTG TA-3') and SeQBW (5'-ACG ATG TCT CCC CTT ACG TG-3'); for P. oceanica $18 S$ rRNA (AY491942), 363 bp (used to check for equal amounts of cDNA template): 18S-FW1 (5'-CAT GGC CGT TCT TAG TTG GT-3') and 18S-BW2 (5'-GTA CAA AGG GCA GGG ACG TA-3'); for the Rubisco large subunit gene (rbcL, U80719), 485 bp: R-FW (5'-ATC TTG GCA GCA TTC CGA GTA-3') and R-BW (5'-AGC CCA CCA CGC AGA CAT T-3'). PCR trials were performed at distinct cycles to assess the variation in transcript abundance before signal saturation, at fixed primer pair and reaction parameters. Amplification products were sequenced to avoid artifacts. PCR reactions were conducted in a $50 \mu$ l total volume containing $3 \mu \mathrm{l}$ of cDNA (other PCR components as given above).

PCR conditions for PoCHL $P$ were $94^{\circ} \mathrm{C}$ for 3 min, 30 cycles of $94^{\circ} \mathrm{C}$ for $50 \mathrm{~s}, 58^{\circ} \mathrm{C}$ for $40 \mathrm{~s}, 72^{\circ} \mathrm{C}$ for $30 \mathrm{~s}$, and $72^{\circ} \mathrm{C}$ for $5 \mathrm{~min}$; for the $18 \mathrm{~S}$ rRNA gene, 18 cycles were used; for $r b c L \mathrm{PCR}$, conditions differed in the number of cycles (30), annealing temperature $\left(55^{\circ} \mathrm{C}\right.$ for $\left.40 \mathrm{~s}\right)$ and extension time $\left(72^{\circ} \mathrm{C}\right.$ for $\left.35 \mathrm{~s}\right)$.

Fifteen $\mu$ l were electrophoresed in a $1 \%$ agarose gel; each signal was determined using quantitative optical densitometry (OD $\pm \mathrm{SD}$ ) based on the pixel intensity/ area of each PCR product as described in Chiappetta et al. (2009). Three replicate analyses were performed and density differences were evaluated using Tukey's test.

Chlorophyll pigments extraction. Experimental procedures followed Bruno et al. (2009a). Three replicate extractions were performed and for each replicate, 6 measurements were carried out on each sample. Statistical analysis was performed using 1-way ANOVA followed by Neuman-Keul's post-hoc test.

\section{RESULTS}

\section{Meadow light conditions}

Light data recorded in the 2 meadows were analyzed using the mean values of compensation $\left(\bar{I}_{\mathrm{c}}=\right.$ $\left.7.8 \pm 1.8 \mu \mathrm{mol} \mathrm{m} \mathrm{m}^{-2} \mathrm{~s}^{-1}\right)$ and saturating $\left(\bar{I}_{k}=73.3 \pm\right.$ $16.1 \mu \mathrm{mol} \mathrm{m} \mathrm{m}^{-2} \mathrm{~s}^{-1}$ ) irradiance, which respectively represent the minimum light available for survival and light conditions for maximum photosynthetic performance estimated for Posidonia oceanica (Lee et al. 2007). Specifically, lux based measurements were converted into photosynthetic photon flux density (PPFD, $\mu \mathrm{mol} \mathrm{m} \mathrm{m}^{-2} \mathrm{~s}^{-1}$ ) according to McCree (1981). The monthly mean values of PPFD for February and April to May were significantly lower, and always below the $\bar{I}_{\mathrm{c}}$ value, for DM than for PM (Fig. 1A-C). These results are consistent with the greater number of days during which light values were recorded to be below the $\bar{I}_{\mathrm{c}}$ value in DM (483 d) than in PM (232 d), with significant differences $(p<0.001)$ being detected in February, April and May (Table S1 in Supplement 1 at www.int-res.com/articles/suppl/m415p061_supp.pdf). In Fig. 1D, the mean PPFD values recorded during the week before the sampling are highlighted. At the T-II interval, which is coincident with the sampling time, light availability was significantly higher in PM compared to DM for all samples. However, values for both meadows were below the $\bar{I}_{\mathrm{c}}$ in June and were higher than the $\bar{I}_{k}$ limit values in November. In April, values were above and below the $\bar{I}_{\mathrm{c}}$ limit for PM and DM, respectively.

Temperature did not differ significantly between the 2 meadows during the entire observation period (Fig. S2 in Supplement 1 at www.int-res.com/articles/ suppl/m415p061_supp.pdf).

\section{PoCHL $P$ features and genomic organization}

The PoCHL $P$ gene (GenBank accession GQ421690) was 2515 nucleotides (nt) long, including an open reading frame (ORF) of $1392 \mathrm{nt}$ and a canonical polyadenylation signal in the 3'UTR region (Fig. 2A). The deduced protein comprised 464 amino acids having a molecular mass of $51.3 \mathrm{kDa}$ (estimated using BioEdit software). The PoCHL P protein exhibited (1) a transit peptide (tp) for cytoplasm-to-chloroplast import, identified using the ChloroP 1.1 prediction server (www.cbs.dtu.dk/services/ChloroP/), (2) 2 signature sequences conserved among CHL P proteins encoding for an enzyme with monoxygenase activity (AttaAsafo-Adjei et al. 1993), and (3) the GXGXXG motif representing the binding site for the NADPH nucleotide moiety (Addlesee \& Hunter 1999).

The PoCHL P protein exhibited highest similarity to the CHL P protein in Arabidopsis thaliana (92\%) followed by those in Nicotiana tabacum (90\%), Glycine max (89\%), Oryza sativa (86\%), Triticum aestivum (85\%), and Synechocystis PCC 6803 (73\%) as evaluated using the BioEdit program (Hall 1999). 
A

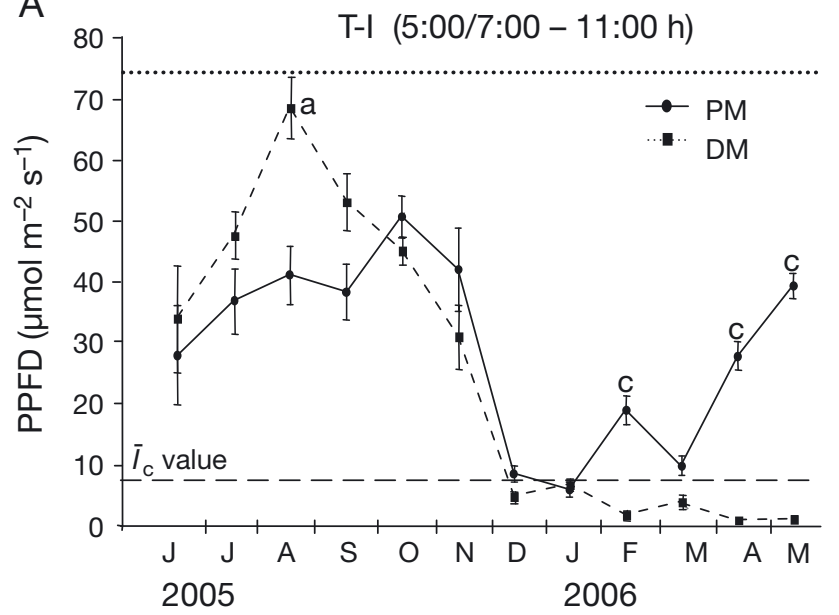

C

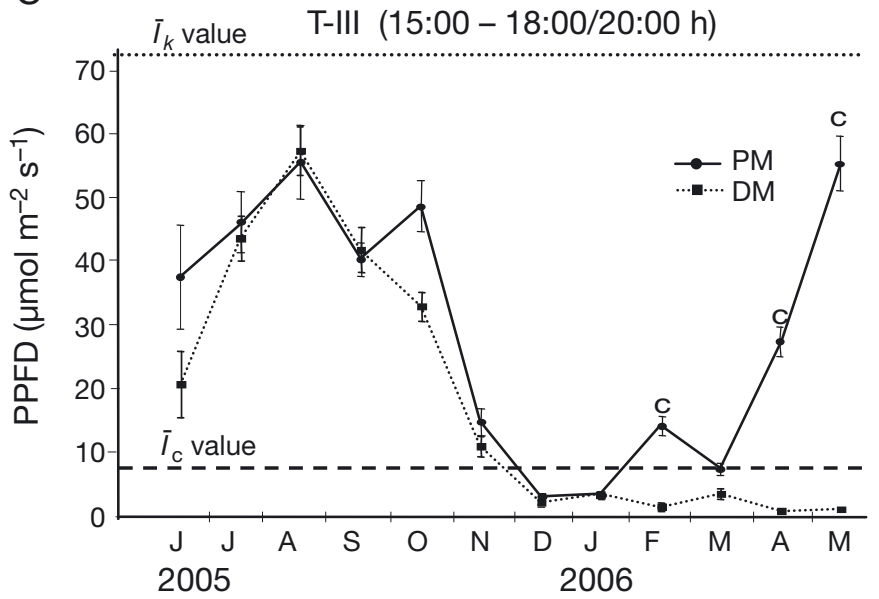

B

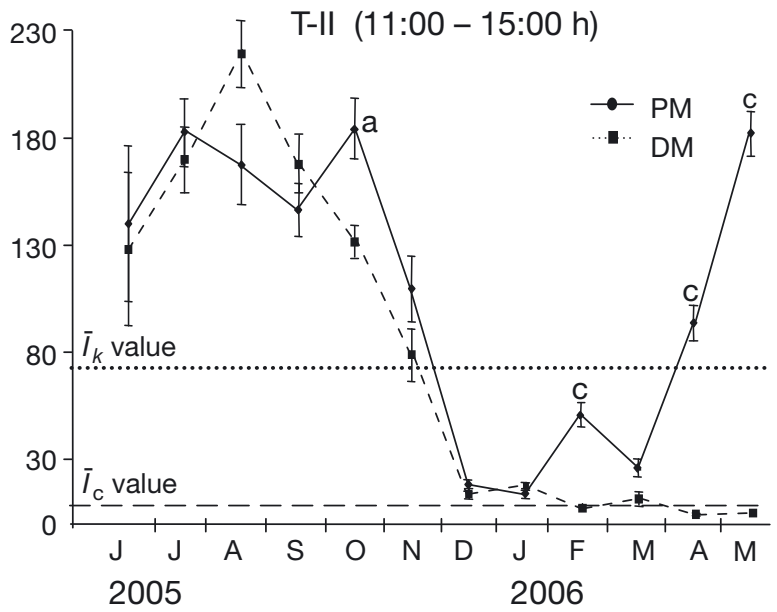

D

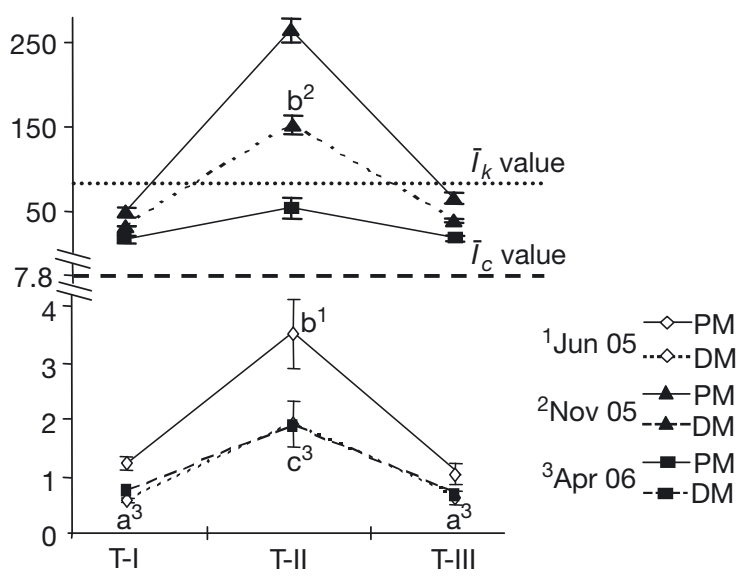

Fig. 1. (A-C) Monthly and (D) weekly mean photosynthetic photon flux density (PPFD) values $\left(\mu m o l \mathrm{~m}^{-2} \mathrm{~s}^{-1} \pm \mathrm{SEM}\right)$ recorded at specific time intervals (T) in preserved (PM) and disturbed (DM) Posidonia oceanica meadows. In (A-C), irradiance compensation mean value $\left(\bar{I}_{\mathrm{c}}=7.8 \pm 1.8 \mu \mathrm{mol} \mathrm{m} \mathrm{m}^{-2} \mathrm{~s}^{-1}\right)$ (horizontal dashed line), and saturating irradiance mean value $\left(\bar{I}_{k}=73.3 \pm\right.$ $16.1 \mu \mathrm{mol} \mathrm{m}{ }^{-2} \mathrm{~s}^{-1}$ ) (dotted line), estimated for P. oceanica (Lee et al. 2007). In (D), the reported values are related to the week before P. oceanica shoot sampling. Statistical analysis: 1-way ANOVA followed by post-hoc Neuman-Keul's test when p-value was significant $(<0.05)$; a: $p<0.05$, b: $p<0.01$, c: $p<0.001$. Superscript numbers indicate significance related to comparisons of specific months

Southern blot analysis (Fig. 2A) produced a single band, thus indicating a single copy of PoCHL $P$ in the $P$. oceanica genome. This observation is consistent with the absence of SNPs in the overlapping fragments (Fig. 2B).

Similar to the CHL P in Arabidopsis (but unlike other reported orthologs), PoCHL $P$ exhibited 2 introns that both harbor the GT/AG editing motif; moreover, the position of the shorter intron was conserved.

\section{PoCHL P tissue-specific expression}

Using RT-PCR, PoCHL $P$ expression was detected in shoot apices, leaves and faintly in roots, whereas transcripts were not detected in rhizomes notwithstanding the high number (i.e. 35) of PCR cycles used (Fig. 3).

Based on these results, in situ hybridizations (ISH) were performed using only shoot apices and leaves at different developmental stages. Gene expression was detected faintly in the shoot apical meristem, but was more intense in leaf primordia and developing leaflets (Fig. 4A). In fully developed leaves of all ages, PoCHL $P$ transcripts accumulated primarily in the epidermal cells, especially along the blade margin (Fig. 4D); the signal in mesophyll tissue was faint and scattered (Fig. 4B,C,E). The phloem vascular bundles were also characterized by a marked signal (Fig. 4B,C,E). 


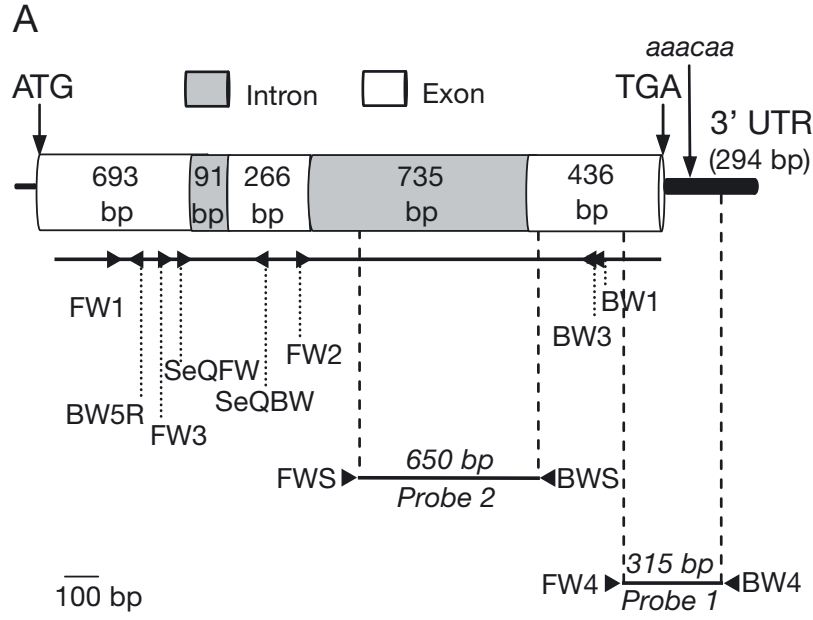

B

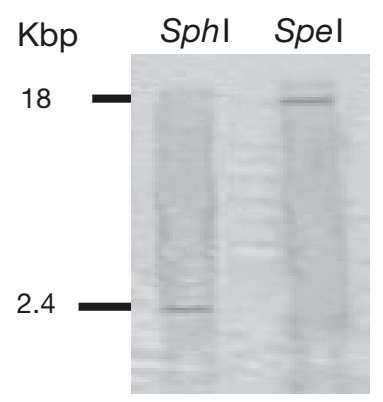

Fig. 2. Posidonia oceanica. PoCHL $P$ gene features. (A) Scheme of the exon/intron organization; numbers inside indicate the length of base pairs (bp). Start and stop codons, polyadenylation signals and untranslated region (UTR) are also indicated. Relative position of probes (black bars), forward (FW) and backward (BW) directed primers (arrows) are shown. (B) Southern blot analysis: genomic DNA digested with $S p h I$ and SpeI restriction endonucleases and hybridized with digoxigenin-labeled probe 2. Molecular weights of co-migrating DNA markers are in kilo base pairs (Kbp)

\section{PoCHL P expression pattern in leaves}

\section{Natural environmental conditions}

PoCHL $P$ expression was evaluated using semiquantitative RT-PCR in leaves (at different developmental stages) taken from plants sampled from PM and DM during June 2005, November 2005 and April 2006 (Fig. 5).

In PM plants, PoCHL $P$ expression was higher in YL and IL compared to AL regardless of the period analyzed (Fig. 5). A comparable pattern was observed in DM plants sampled in November 2005, while an opposite trend was detected in DM plants sampled in June 2005 and April 2006 where gene expression was weaker in YL and IL as compared to AL (Fig. 5).

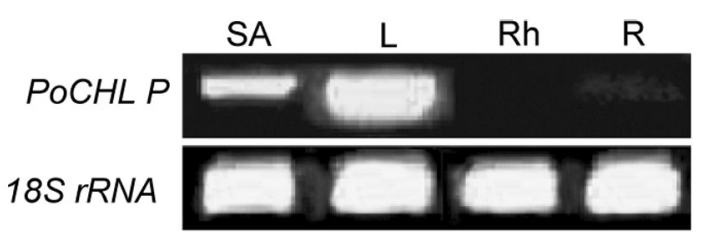

Fig. 3. Posidonia oceanica. PoCHL $P$ gene expression in shoot apices (SA), leaves (L), rhizomes (Rh) and roots (R) estimated by 35 cycles of RT-PCR. Expression of the 18S rRNA gene is also reported

\section{Controlled light conditions}

PoCHL $P$ expression was evaluated in plants grown under controlled light conditions in aquaria. Plants sampled in April were chosen for this experiment because of their active physiological state and high growth rate. Two light treatments were applied: L1 $\left(\right.$ mean $\left.\pm \mathrm{SE}, \mathrm{PPFD}=3.37 \pm 0.5 \mu \mathrm{mol} \mathrm{m} \mathrm{m}^{-2} \mathrm{~s}^{-1}\right)$ and $\mathrm{L} 2$ $\left(\mathrm{PPFD}=1.7 \pm 0.4 \mu \mathrm{mol} \mathrm{m}{ }^{-2} \mathrm{~s}^{-1}\right)$, which corresponded to PPFD values at which differences in gene expression between plants from the 2 meadows had been previously detected (i.e. June 2005 sampling).

For PM plants, the switch from environmental to L1 conditions did not modify PoCHL $P$ expression in the leaves, whereas the pattern of gene expression under L2 conditions was quite comparable to that observed under environmentally disturbed conditions (DM plants) (Fig. 5). In contrast, exposure of DM plants to L1 conditions affected their PoCHL $P$ expression pattern, yielding results similar to those of PM plants although transcription in YL still appeared to be down regulated (Fig. 5). Under L2 conditions, PoCHL $P$ expression in DM plants was almost unchanged, with the exception of a higher expression level in IL compared to IL expression in environmentally disturbed conditions.

In both the field and aquarium experiments, the expression pattern of the rbcL gene (a marker of photosynthetic activity) overlapped with that observed for PoCHL $P$.

\section{Leaf chlorophyll content}

Total chl content generally increased during leaf development, with the lowest values being detected in YL (Table 1). Furthermore, for naturally growing plants, the total chl content was higher in YL of DM vs. those of PM in June 2005 and April 2006; a reduced chl content was observed in IL of DM vs. those of PM plants in November 2005 (Table 1A).

In aquarium experiments, chl content increased in the leaves of DM plants exposed to L2 conditions 

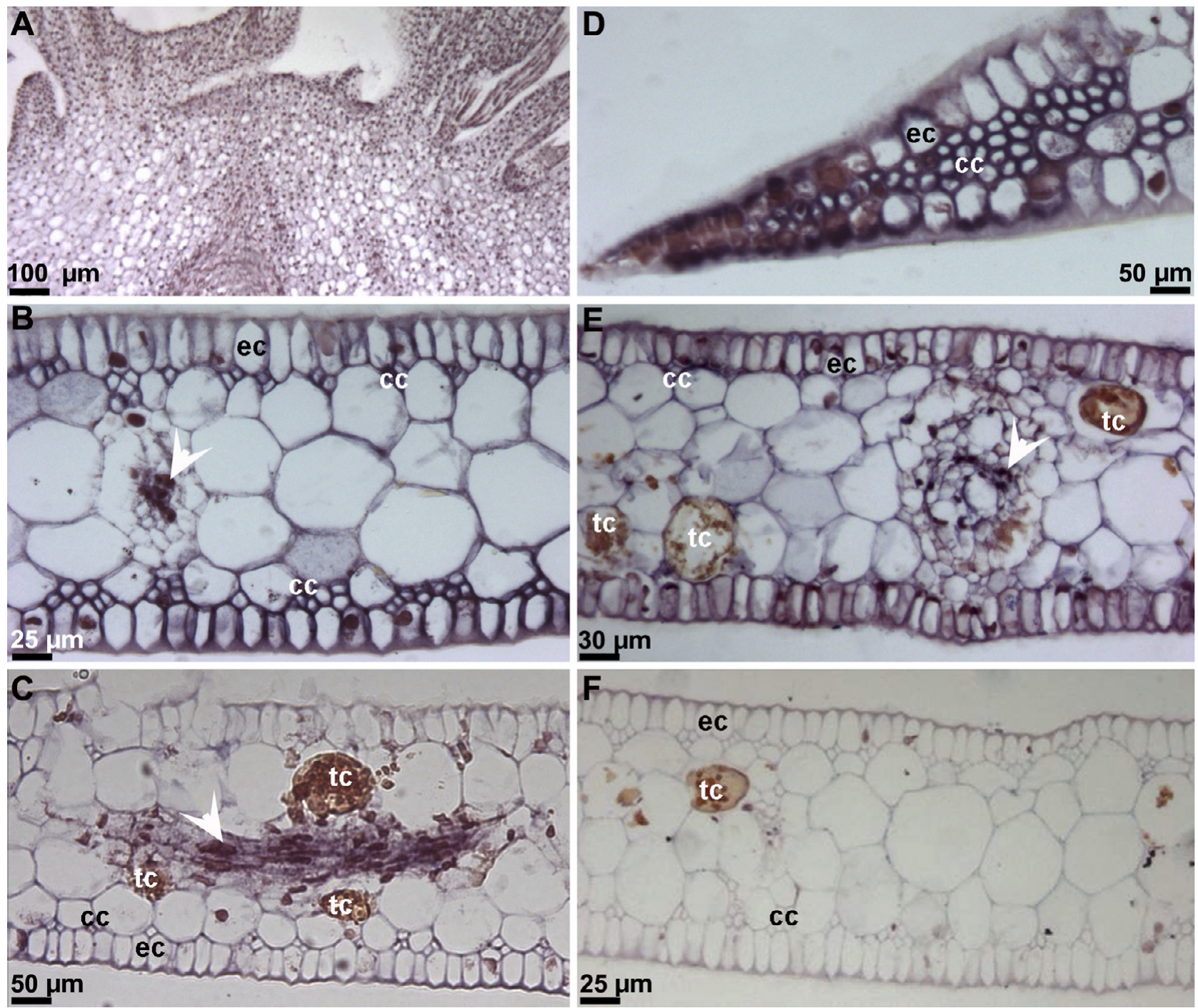

Fig. 4. Posidonia oceanica. In situ localization of PoCHL P mRNAs (violet signal) on (A) shoot apex longitudinal section and (B-F) leaf cross sections; (B-D) young leaf, $(\mathrm{E}-\mathrm{F})$ intermediate leaf, $(\mathrm{A}-\mathrm{E})$ samples treated with anti-sense probe. (F) Leaf treated with sense probe as negative control. ec: epidermal cells, cc: collenchyma cells, tc: tannin cells, white arrowhead: phloematic portion of vascular bundles

regardless of their developmental stage (Table 1B). However, in both naturally growing and aquarium plants, the $\mathrm{chl} a / b$ ratio remained relatively constant, ranging from $1.81 \pm 0.06$ to $2.82 \pm 0.09$ (Table S2 in Supplement 1 at www.int-res.com/articles/suppl/ m415p061_supp.pdf).

\section{DISCUSSION}

Here, we demonstrate that the PoCHL $P$ gene of Posidonia oceanica is expressed differentially with respect to both endogenous developmental cues and stressful light conditions, in a manner comparable to that found in terrestrial plants (Giannino et al. 2004,
Bruno et al. 2009a). Indeed, this report represents the first functional characterization of a light-stress related gene in any seagrass analyzed under different environmental conditions.

The CHL $P$ gene encodes a protein with a multifunctional metabolic role that is closely associated with chloroplast differentiation and protection (Keller et al. 1998). In Posidonia oceanica, PoCHL $P$ was expressed primarily in the leaves and transcripts accumulated mainly in the epidermal layer. This observation is consistent with the anatomy of Posidonia leaves in which the epidermal cells harbor numerous chloroplasts in contrast to the mesophyll cells; the latter contain few chloroplasts and exhibit large vacuoles that are often entirely filled with phenolics (Mariani Colombo et al. 


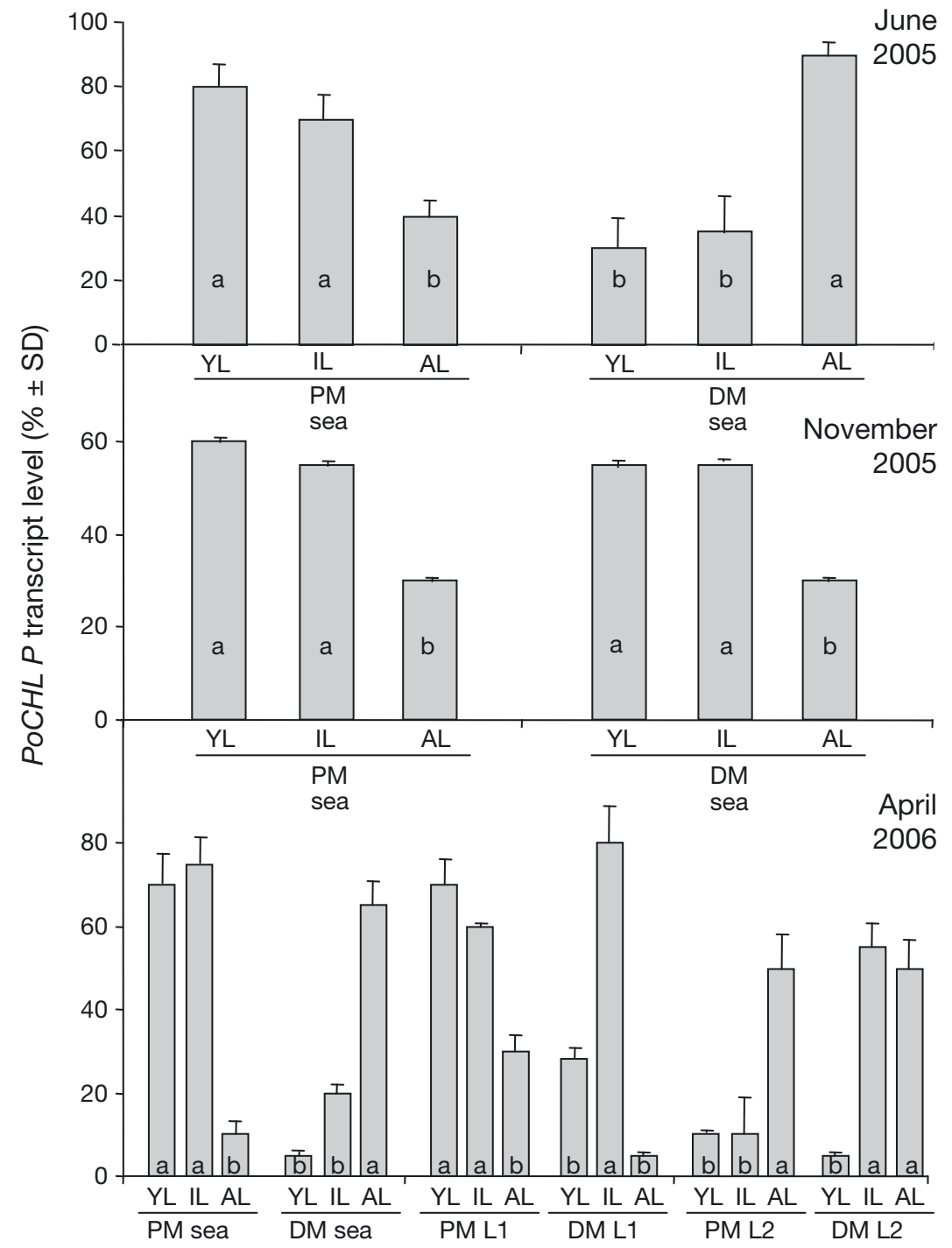

Fig. 5. Posidonia oceanica. Relative levels of PoCHL $P$ transcripts, normalized with the $18 S$ rRNA gene, in plants sampled from preserved (PM) and disturbed meadows (DM) at different seasons and grown in the natural environment or in aquaria under controlled light conditions $\left(\mathrm{L} 1=1.7 \pm 0.4 \mu \mathrm{mol} \mathrm{m}{ }^{-2} \mathrm{~s}^{-1}\right.$ and $\mathrm{L} 2=$ $3.37 \pm 0.5 \mu \mathrm{mol} \mathrm{m}{ }^{-2} \mathrm{~s}^{-1}$ ). Relative levels of PoCHL $P$ transcripts were estimated by quantitative densitometry of the PCR products resolved by electrophoresis. All columns marked with the same letter are not significantly different at $p=$ 0.05 (Tukey's test). YL: young leaf, IL: intermediate leaf, AL: adult leaf

As reported in terrestrial plants (Giannino et al. 2004, Bruno et al. 2009a), our results showed that $P O C H L P$ is also expressed differentially in leaves with respect to their developmental stage. However, the pattern of gene expression did not overlap between plants growing in different meadows that were previously categorized as preserved (PM) and disturbed (DM) sites for Posidonia oceanica based on several relevant fitness parameters (Cozza et al. 2004, Rende et al. 2005, Acunto et al. 2006, Bruno et al. 2009b). Indeed, in plants from preserved sites, PoCHL P expression was higher in fast-growing YL and IL than in AL - an observation that is consistent with the pattern described for pluriannual vs. deciduous leaves of terrestrial plants (Bruno et al. 2009a). In contrast, plants from disturbed sites exhibited such a pattern only in the autumn sampling. Instead, a down regulation of gene expression was detected in YL and IL of DM vs. those of PM plants during late spring and early summer. At the same time, AL, which are characterized by a slow growth rate, exhibited higher gene expression in DM compared to PM plants. Consistent with photoadaptive responses to modified light conditions reported elsewhere (e.g. Tomasko 1993), a different modulation of chl content in relation to developmental stage was also observed in PM vs. DM plants, together with a chl $a / b$ ratio that is analogous to that reported by Pirc (1986) for P. oceanica. All these results suggest different photosynthetic competence in PM vs. DM plants.

The expression of the $r b c L$ gene in Posidonia oceanica leaves varied with environmental conditions and consistently overlapped with that of $P O C H L P$.

1983, Cozza et al. 2004). Notably, PoCHL $P$ transcripts were also detected in the leaf phloem tissue - a finding that has not been previously reported (Giannino et al. 2004, Bruno et al. 2009a). Because the CHL P gene functions in the biosynthesis of TP and chl, its expression in the phloem could be linked to a proposed role of TP in regulating the translocation of photoassimilates through the modulation of symplastic continuity between the bundle sheath and vascular parenchyma (Hofius et al. 2004, Abbasi et al. 2007, Maeda \& DellaPenna 2007).
Thus, it is reasonable, at least in this case, for PoCHL $P$ expression to provide an indirect link to photosynthetic activity. In this context, the down regulation of both these genes in YL and IL of DM plants is consistent with the observed reduction in leaf growth rate that was previously recorded in DM (Rende et al. 2005, Acunto et al. 2006, Rende et al. 2006). Notably, the monthly mean irradiance recorded in the DM site for 3 consecutive months during spring (a period that is coincident with carbohydrate storage in the rhizome; Pirc 1985, Alcoverro et al. 2001) was lower than the $\bar{I}_{\mathrm{C}}$, which represents 
Table 1. Posidonia oceanica. Total chlorophyll content in leaves sampled from preserved (PM) and disturbed meadows (DM) (A) at different periods and (B) after $1 \mathrm{wk}$ of aquarium treatment at L1 and L2. YL: young leaf, IL: intermediate leaf, AL: adult leaf. Statistical analysis: 1-way ANOVA followed by Neuman Keul's post-hoc test; ${ }^{*} \mathrm{p}<0.05,{ }^{* *} \mathrm{p}<0.01,{ }^{* * *} \mathrm{p}<0.001$

\begin{tabular}{|c|c|c|c|}
\hline \multirow{2}{*}{$\begin{array}{l}\text { Sampling } \\
\text { period and } \\
\text { site }\end{array}$} & \multicolumn{3}{|c|}{$\begin{array}{c}\text { Total chl } \\
\left(\mathrm{mg} \mathrm{g}^{-1} \text { fresh weight } \pm \text { SEM }\right)\end{array}$} \\
\hline & YL & IL & $\mathrm{AL}$ \\
\hline \multicolumn{4}{|c|}{ (A) Meadows (Sea) } \\
\hline \multicolumn{4}{|c|}{ June 2005} \\
\hline $\mathrm{PM}$ & $0.054 \pm 0.01$ & $0.581 \pm 0.03$ & $0.644 \pm 0.02$ \\
\hline DM & $0.314 \pm 0.03^{*}$ & $0.513 \pm 0.03$ & $0.516 \pm 0.02$ \\
\hline \multicolumn{4}{|c|}{ November 2005} \\
\hline $\mathrm{PM}$ & $0.087 \pm 0.01$ & $0.754 \pm 0.02$ & $0.978 \pm 0.04$ \\
\hline $\mathrm{DM}$ & $0.201 \pm 0.02$ & $0.442 \pm 0.01^{*}$ & $0.723 \pm 0.04$ \\
\hline \multicolumn{4}{|l|}{ April 2006} \\
\hline PM & $0.155 \pm 0.06$ & $0.681 \pm 0.01$ & $0.839 \pm 0.01$ \\
\hline $\mathrm{DM}$ & $0.413 \pm 0.01^{* * *}$ & $0.643 \pm 0.03$ & $0.716 \pm 0.03$ \\
\hline \multicolumn{4}{|l|}{ (B) Aquaria } \\
\hline \multicolumn{4}{|l|}{ April 2006} \\
\hline PM-L1 & $0.071 \pm 0.01$ & $0.646 \pm 0.01$ & $0.681 \pm 0.04$ \\
\hline PM-L2 & $0.385 \pm 0.05^{* * *}$ & $0.509 \pm 0.07$ & $0.641 \pm 0.01$ \\
\hline DM-L1 & $0.234 \pm 0.06$ & $0.301 \pm 0.03$ & $0.692 \pm 0.02$ \\
\hline DM-L2 & $0.368 \pm 0.01^{*}$ & $0.450 \pm 0.04^{* *}$ & $1.242 \pm 0.05^{* * *}$ \\
\hline
\end{tabular}

minimal light requirements to sustain optimal growth of P. oceanica (Lee et al. 2007). Resource depletion associated with such prolonged periods of low irradiance $\left(<\bar{I}_{\mathrm{c}}\right)$ could possibly account for reduced growth rates in DM (Alcoverro et al. 2001). However, a high level of $r b c L$ and $P o C H L P$ expression was detected in AL of DM vs. those of PM plants. Given the subsidiary role of $C H L P$ in both chl and TP biosynthesis, the similar levels of chl in AL of PM and DM plants prompt us to speculate that the high level of PoCHL $P$ expression in these leaves may be related to TP requirement as an adaptive response to shield plants from both oxidative and aging processes (Weaver \& Amasino 2001, Havaux et al. 2005). Oxidative and aging processes could precociously occur in AL of PM plants due to the absence of adequate levels of cytokinins (Cozza et al. 2004), which are known to play a key role in preventing leaf senescence. Moreover, TP might be required to sustain resource translocation (Hofius et al. 2004) at a critical moment in the plant life cycle. This is suggested by our evidence of localized gene activity in vascular tissue as well as by the changes in the pattern of PoCHL $P$ expression that were observed in the leaves of DM plants at very critical light conditions for plant growth (mean $\pm \mathrm{SE}, 1.7 \pm 0.4 \mu \mathrm{mol} \mathrm{m} \mathrm{m}^{-2} \mathrm{~s}^{-1}$ ). However, because we did not experimentally investigate the fluxes through these pathways, further investigations are necessary to tightly relate gene expression with the overall metabolic state of plants.
Our results also demonstrated that temperature did not modulate PoCHL $P$ transcriptional activity within the thermal range normally experienced in this marine environment. Indeed, the pattern of PoCHL P expression in DM plants sampled in April and June was quite comparable despite the observed variation in temperature (15.5 to $22.8^{\circ} \mathrm{C}$ ). Interestingly, $\mathrm{PM}$ plants grown in an aquarium for $1 \mathrm{wk}$ at $1.7 \pm 0.4 \mu \mathrm{mol} \mathrm{m} \mathrm{m}^{-2} \mathrm{~s}^{-1}$ exhibited a pattern comparable to that recorded in DM plants under corresponding natural light conditions independent of temperature. Thus, critical light conditions over periods of $<1$ wk can switch the pattern of gene expression in leaves. Notably, a reversion to the PM pattern was obtained in aquarium grown DM plants at $3.7 \pm 0.5 \mu \mathrm{mol}$ $\mathrm{m}^{-2} \mathrm{~s}^{-1}$, although partial gene expression in YL leaves indicated that the reversion was incomplete.

In conclusion, our results showed that the pattern of CHL P expression in Posidonia oceanica is modulated by light conditions and is related to both the differentiation and metabolic status of the leaves. This finding is consistent with other reports indicating that seagrasses can reconfigure their physiology in relation to the photo-acclimation process (Neverauskas 1988, Ruiz \& Romero 2001). In this context, it should be noted that our light data was derived from lux measurements. However, this is not critically important, as the relevant light values recorded in this work are close to, or are below the $\bar{I}_{\mathrm{c}}$ and substantially lower than the $\bar{I}_{\mathrm{k}}$. Hence, we have interpreted the laboratory and field data in relation to relative as opposed to absolute differences in light intensity. Notably, the narrow window of irradiance values ( 3.7 to $1.7 \mu \mathrm{mol} \mathrm{m} \mathrm{m}^{-2} \mathrm{~s}^{-1}$ ), which can induce changes in $\mathrm{PoCHL} P$ expression, indicates that this gene is a reasonable molecular marker for evaluating the extent of stress imposed by low light levels in $P$. oceanica. Hence, this study of the PoCHL $P$ gene provides some novel insights into the development and application of molecular environmental indicators for seagrasses, and in particular, the management of $P$. oceanica ecosystems. However, the rapid alteration of gene activity in response to changes in irradiance makes PoCHL $P$ expression an unsuitable marker for meadow-monitoring activities, which seek to provide information over longer time scales.

Acknowledgements. We thank F. Rende and M. Cardilio for help in collecting plant material, and 3 anonymous reviewers for useful comments and suggestions on the manuscript.

\section{LITERATURE CITED}

Abbasi AR, Hajirezaei M, Hofius D, Sonnewald U, Voll LM (2007) Specific roles of $\alpha$ - and $\gamma$-tocopherol in abiotic stress responses of transgenic tobacco. Plant Physiol 143: $1720-1738$ 
Acunto S, Rende F, Cozza R, Innocenti AM (2006) State of health of Posidonia oceanica meadows along the northern Tyrrhenian coast of Calabria, Italy. Biol Mar Mediterr 13: 8-13

> Addlesee HA, Hunter CN (1999) Physical mapping and functional assignment of the geranylgeranyl-bacteriochlorophyll reductase gene, bchP, of Rhodobacter sphaeroides. J Bacteriol 181:7248-7255

Addlesee HA, Gibson LCD, Jensen PE, Hunter CN (1996) Cloning, sequencing and functional assignment of the chlorophyll biosynthesis gene, chlP, of Synechocystis sp. PCC 6803. FEBS Lett 389:126-130

Alcoverro T, Duarte CM, Romero J (1997) Influence of herbivores on Posidonia oceanica epiphytes. Aquat Bot 56: 93-104

> Alcoverro T, Manzanera M, Romero J (2001) Annual metabolic carbon balance of the seagrass Posidonia oceanica: the importance of carbohydrate reserves. Mar Ecol Prog Ser 211:105-116

> Alexandrov NN, Brover VV, Freidin S, Troukhan ME and others (2009) Insights into corn genes derived from largescale cDNA sequencing. Plant Mol Biol 69:179-194

> Atta-Asafo-Adjei E, Lawon MP, Philpot R (1993) Cloning, sequencing, distribution, and expression in Escherichia coli of flavin-containing monooxygenase 1C1. J Biol Chem 268:9681-9689

Bollivar DW, Wang SJ, Allen JP, Bauer CE (1994) Molecular genetic analysis of terminal steps in bacteriochlorophyll a biosynthesis: characterization of a Rhodobacter capsulatus strain that synthesizes geranylgeraniol-esterified bacteriochlorophyll a. Biochemistry 33:12763-12768

Bruno L, Chiappetta A, Muzzalupo I, Gagliardi C and others (2009a) Role of geranylgeranyl reductase gene in organ development and stress response in olive (Olea europaea) plants. Funct Plant Biol 36:370-381

Bruno A, Petrarulo M, Salimonti A, Chiappetta A, Bitonti MB (2009b) Distinct pattern of zeatin distribution in the shoot apical meristem marks stress condition in Posidonia oceanica (L.) Delile plants. Plant Biosyst 143:25-33

Cañas LA, Busscher M, Angenent GC, Beltrá JP, van Tunen AJ (1994) Nuclear localization of the petunia MADS box protein FBP1. Plant J 6:597-604

Cancemi G, Giovanni DF, Pergent G (2003) Effects of organic matter input from a fish farming facility on a Posidonia oceanica meadow. Estuar Coast Shelf Sci 56:961-968

> Chiappetta A, Fambrini M, Petrarulo M, Rapparini F and others (2009) Ectopic expression of LEAFY COTYLEDON1LIKE gene and localized auxin accumulation mark embryogenic competence in epiphyllous plants of Helianthus annuus $\times$ H. tuberosus. Ann Bot 103:735-747

Cozza R, Pangaro T (2009) Tissue expression pattern of two aquaporin-encoding genes in different organs of the seagrass Posidonia oceanica. Aquat Bot 91:117-121

Cozza R, Chiappetta A, Petrarulo M, Salimonti A, Rende F, Bitonti MB, Innocenti AM (2004) Cytophysiological features of Posidonia oceanica as putative markers of environmental conditions. Chem Ecol 20:215-223

Cozza R, Pangaro T, Maestrini P, Giordani T, Natali L, Cavallini A (2006) Isolation of putative type 2 metallothionein encoding sequences and spatial expression pattern in the seagrass Posidonia oceanica. Aquat Bot 85:317-323

Davies PJ (1995). The plant hormones: their nature, occurrence, and functions. In: Davies PJ (ed) Plant hormones: physiology, biochemistry and molecular biology. Kluwer Academic, Dordrecht, p 1-12

> Dennison WC (1987) Effects of light on seagrass photosynthesis, growth and depth distribution. Aquat Bot 27:15-26
Doyle JJ, Doyle JL (1990) Isolation of plant DNA from fresh tissue. Focus 12:13-15

> Duarte M (1991) Seagrass depth limits. Aquat Bot 40:363-377

Ferrat L, Pergent-Martini C, Romero M (2003) Assessment of the use of biomarkers in aquatic plants for the evaluation of environmental quality: application to seagrasses. Aquat Toxicol 65:187-204

Giannino D, Condello E, Bruno L, Testone G and others (2004) The gene geranylgeranyl reductase of peach (Prunus persica (L.) Batsch) is regulated during leaf development and responds differentially to distinct stress factors. J Exp Bot 55:2063-2073

> Giordani T, Natali L, Maserti BE, Taddei S, Cavallini A (2000) Characterization and expression of DNA sequences encoding putative type-II metallothioneins in the seagrass Posidonia oceanica. Plant Physiol 123:1571-1582

Giraud G (1977) Essai de classement des herbiers de Posidonia oceanica (Linnè) Delile. Bot Mar 20:487-491

Hall TA (1999) BioEdit: a user-friendly biological sequence alignment editor and analysis program for Windows 95/98/NT. Nucleic Acids Symp Ser 41:95-98

> Havaux M, Eymery F, Porfirova S, Rey P, Dörmann P (2005) Vitamin E protects against photoinhibition and photooxidative stress in Arabidopsis thaliana. Plant Cell 17: 3451-3469

Hofius D, Hajirezaei MR, Geiger M, Tschiersch H, Melzer M, Sonnewald U (2004) RNAi-mediated tocopherol deficiency impairs photoassimilate export in transgenic potato plants. Plant Physiol 135:1256-1268

> Hutchison CE, Kieber JJ (2002) Cytokinin signaling in Arabidopsis. Plant Cell 14:S47-S59

> International Rice Genome Sequencing Project (2005) The map-based sequence of the rice genome. Nature 436: 793-800

Jeudy de Grissac A, Boudouresque CF (1985) Rôles des herbier de phanérogames marines dans les mouvements des sédiments côtiers: les herbiers à Posidonia oceanica. Colloq Fr-Japon Océanogr 1:143-151

> Kamal-Eldin A, Appelqvist LA (1996) The chemistry and antioxidant properties of tocopherols and tocotrienols. Lipids 31:671-701

Keller Y, Bouvier F, D'Harlingue A, Camara B (1998) Metabolic compartmentation of plastid prenyllipid biosynthesis: evidence for the involvement of a multifunctional geranylgeranyl reductase. Eur J Biochem 251:413-417

Lafabrie C, Pergent G, Pergent-Martini C, Capiomont A (2007) Posidonia oceanica: a tracer of past mercury contamination. Environ Pollut 148:688-692

Lee KS, Park SR, Kim YK (2007) Effects of irradiance, temperature, and nutrients on growth dynamics of seagrasses: a review. J Exp Mar Biol Ecol 350:144-175

> Lin JF, Wu SH (2004) Molecular events in senescing Arabidopsis leaves. Plant J 39:612-628

> Maeda H, DellaPenna D (2007) Tocopherol functions in photosynthetic organisms. Curr Opin Plant Biol 10:260-265

- Marbà N, Duarte CM, Cebrián J, Gallegos ME, Olesen B, Sand-Jensen K (1996) Growth and population dynamics of Posidonia oceanica on the Spanish Mediterranean coast: elucidating seagrass decline. Mar Ecol Prog Ser 137: 203-213

> Mariani Colombo P, Rascio N, Cinelli F (1983) Posidonia oceanica (L.) Delile: a structural study of the photosynthetic apparatus. PSZN I: Mar Ecol 4:133-145

> Mazzuca S, Spadafora A, Filadoro D, Vannini C and others (2009) Seagrass light acclimation: 2-DE protein analysis in Posidonia leaves grown in chronic low light conditions. J Exp Mar Biol Ecol 374:113-122 
McCree KJ (1981). Photosynthetically active radiation. In: Lang OL, Novel P, Osmond B, Ziegler H (eds) Physiological plant ecology. Encyclopedia of plant physiology (new series), Vol 12A. Springer-Verlag, Berlin

Monte E, Al-Sady B, Leivar P, Quail PH (2007) Out of the dark, how the PIFs are unmasking a dual temporal mechanism of phytochrome signalling. J Exp Bot 58:3125-3133

Montefalcone M (2009) Ecosystem health assessment using the Mediterranean seagrass Posidonia oceanica: a review. Ecol Indic 9:595-604

Neverauskas VP (1988) Response of a Posidonia community to prolonged reduction in light. Aquat Bot 31:361-366

Ott JA (1979) Persistence of a seasonal growth rhythm in Posidonia oceanica (L.) Delile under constant conditions of temperature and illumination. Mar Biol Lett 1:99-104

Pergent G, Pergent-Martini C, Boudouresque CF (1995) Utilisation de l'herbier à Posidonia oceanica comme indicateur biologique de la qualité du milieu littoral en Méditerranée: état de connaissances. Mésogée 54:3-29

Pergent-Martini C, Rico-Raimondino V, Pergent G (1994) Primary production of Posidonia oceanica in the Mediterranean basin. Mar Biol 120:9-15

> Pirc H (1985) Growth dynamics in Posidonia oceanica (L.) Delile. I. Seasonal changes of soluble carbohydrates, starch, free amino acids, nitrogen and organic anions in different parts of the plant. PSZN I: Mar Ecol 6:141-165

Pirc H (1986) Seasonal aspects of photosynthesis in Posidonia oceanica: influence of depth, temperature and light intensity. Aquat Bot 26:203-212

Rende F, Cardilio M, Cozza R, Innocenti AM (2005) Monitoring of Posidonia oceanica (L) Delile beds in Dino island SIC site. Biol Mar Mediterr 12:436-441

Rende F, Cozza R, Innocenti AM (2006) Growth dynamics of Posidonia oceanica (L) Delile meadows in different environmental conditions. Biol Mar Mediterr 13:629-632

Editorial responsibility: Just Cebrian, Dauphin Island, Alabama, USA
Ruiz JM, Romero J (2001) Effects of in situ experimental shading on the Mediterranean seagrass Posidonia oceanica. Mar Ecol Prog Ser 215:107-120

> Ruiz JM, Romero J (2003) Effects of disturbances caused by coastal constructions on spatial structure, growth dynamics and photosynthesis of the seagrass Posidonia oceanica. Mar Pollut Bull 46:1523-1533

Short FT, Wyllie-Echeverria S (1996) Natural and humaninduced disturbance of seagrasses. Environ Conserv 23: $17-27$

Sweere U, Eichenberg K, Lohrmann J, Mira-Rodado V and others (2001) Interaction of the response regulator ARR4 with the photoreceptor phytochrome B in modulating red light signaling. Science 294:1108-1111

Tomasko DA (1993) The physiological basis for responses to light availability. In: Morris LJ, Tomasko DA (eds) Proceedings and conclusions of workshops on the submerged aquatic vegetation initiative and photosynthetically active radiation. Special Publication SJ93-SP13, St. Johns River Water Management District, Palatka, FL, p 211-218

- Tranchina L, Miccichè S, Bartolotta A, Brai M, Mantegna RN (2005) Posidonia oceanica as a historical monitor device of lead concentration in marine environment. Environ Sci Technol 39:3006-3012

Weaver LM, Amasino RM (2001) Senescence is induced in individually darkened Arabidopsis leaves, but inhibited in whole darkened plants. Plant Physiol 127:876-886

Wissler L, Dattolo E, Moore AD, Reusch TBH, Olsen JL, Migliaccio M, Procaccini G (2009) Dr. Zompo: an online data repository for Zostera marina and Posidonia oceanica ESTs. Database bap009 doi:10.1093/database/bap009

Zupo V, Buia MC, Mazzella L (1997) A production model for Posidonia oceanica based on temperature. Estuar Coast Shelf Sci 44:483-492

Submitted: August 31, 2009; Accepted: July 5, 2010 Proofs received from author(s): September 6, 2010 